\title{
ROBO2 Gene
}

National Cancer Institute

\section{Source}

National Cancer Institute. ROBO2 Gene. NCI Thesaurus. Code C126774.

This gene plays a role in lig and binding, axon guidance and cell migration. 